\section{Project Development and Finance}

\section{NREL Expertise Reduces Risk, Gets Projects Done}

The National Renewable Energy Laboratory (NREL) is the U.S. Energy Department's only national laboratory focused on renewable energy and energy efficiency. For 35 years, our work with the public and private sectors to ensure successful energy research, development, analysis, commercialization, and deployment has catalyzed the emergence of a clean energy industry.

NREL works with federal agency, military, state/local/tribal government, corporate, and international decision makers to help identify project goals, develop energy portfolios, implement projects, conduct financial analysis, and provide transaction guidance. We begin by gaining an understanding of our clients' long-term objectives, available energy resources, relevant market dynamics, technological options, and environmental and social requirements. We then identify energy efficiency and renewable energy opportunities and constraints, working with our clients to develop implementation strategies that may involve single projects or a broader portfolio.

Our team is experienced in moving projects from technical possibility to risk assessment and business case development through transaction to operation. Through public outreach and stakeholder engagement and education, we address the human factors that make or break a project.

\section{Project Development}

NREL helps clients clarify and manage risk in energy resources, project costs, evolving regulatory and permitting regimes, and retail markets. We support the full project development process from feasibility studies and due diligence through siting, execution, and commissioning, including:

- Site Screening. We evaluate site factors such as renewable energy and energy efficiency potential, active energy efficiency measures, greenfield/brownfield opportunities,

and transmission infrastructure.

- Energy Technology Assessment. Using our models and tools, we provide the foremost expertise on the latest renewable energy, efficiency, and grid technologies.

- Business Case Development. We help evaluate feasibility, risk mitigation, project costs, and tariff projections.
Practice Areas

Sustainable energy opportunity assessments

Business case development

Energy technology assessments

Net-zero energy planning

Project and portfolio development

Renewable energy implementation roadmaps

Procurement strategies

Project valuation

Stakeholder engagement, education, and outreach

Selection among project finance alternatives

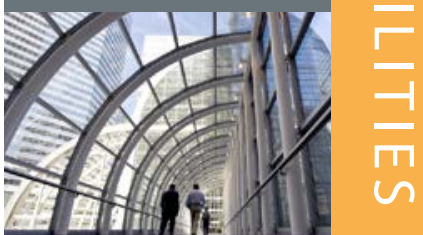

We offer a broad range of advisory services including renewable energy policy design, market and technology assessment, energy portfolio deployment, finance advising, and project implementation assistance.

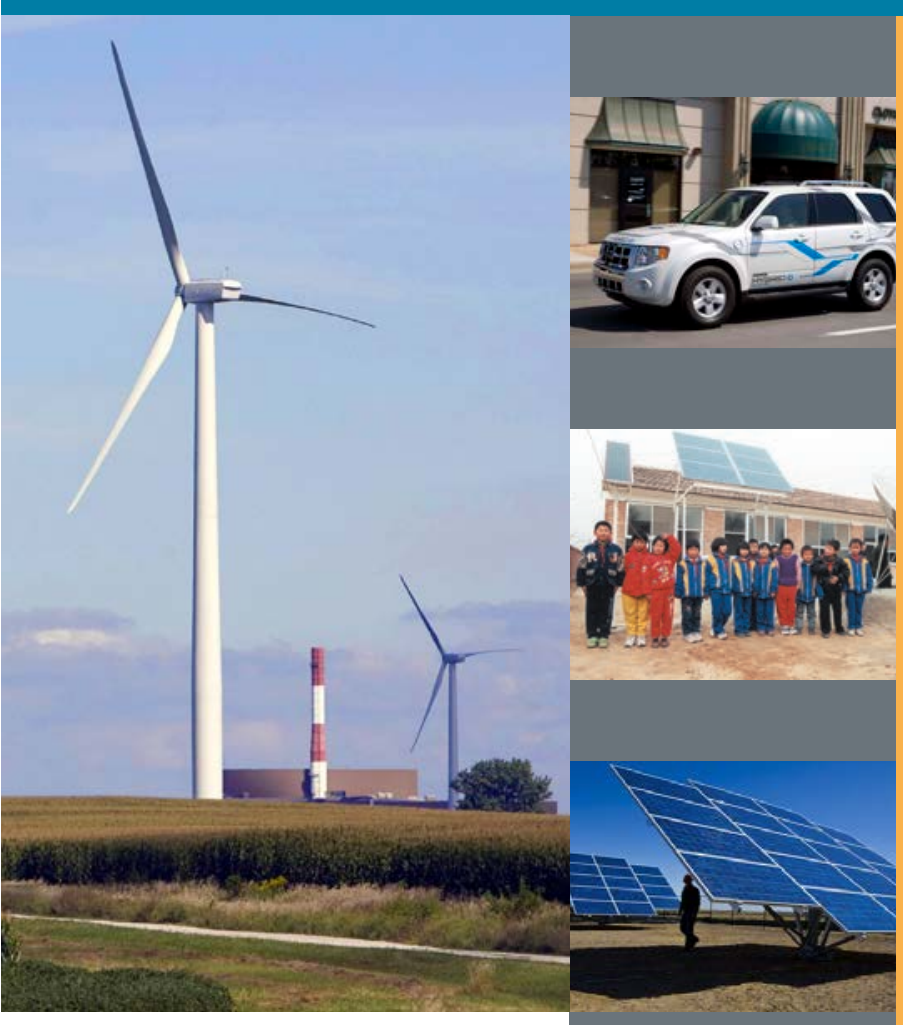


- Procurement Strategy. Our team of experts can help stakeholders understand the complete spectrum of project contracts and documents, development processes, and acquisition methods.

\section{Project Economics and Finance}

We help analyze project economics; identify effective project funding alternatives, including various financing mechanism and ownership structures; and develop public and private deployment strategies for energy efficiency measures and large-scale renewable energy projects.

\section{- Renewable Energy Valuation.}

We conduct and review project valuations, analyze rates of return for different investors, and identify potential risks for different deal structures across the spectrum of renewable energy technologies.

- Evaluation of Project Economics. We develop financial pro-formas for energy technologies, conduct sensitivity analyses based on project drivers, identify risks, and recommend deal structures.

\section{- Identification of Available Incentives.} Our team has experience with investment and production tax credits, grants, bond financing, and other types of national, state, and local incentives.

\section{Examples of Our Clients and Projects}

\section{Net-Zero Energy Planning for the U.S. Department of Defense}

Our team works extensively with all branches of the military to conduct holistic energy assessments for installations around the globe. Several installations have implemented our recommendations and are on their way to net-zero energy status.

\section{State of Hawaii Clean Energy Initiative}

As just one part to NREL's larger role in the Hawaii Clean Energy Initiative, we provided early development support on larger energy infrastructure projects ranging in size from a 2.3-megawatt (MW) wind farm to a 400-MW wind farm with an undersea transmission cable.

\section{U.S. Department of Treasury Grant Program (1603)}

Our staff members performed technical reviews supporting the Treasury Department's 1603 grant program, facilitating the award of $\$ 50$ billion in renewable energy incentives.

\section{Asian Development Bank}

We provided renewable energy and project development training to the private financial sector in India, facilitating the installation of more than 1 gigawatt of privately owned solar projects in two years.

\section{Millennium Challenge Corporation}

NREL is helping the Millennium Challenge Corporation identify renewable energy opportunities that will fuel economic growth in Indonesia.
NREL's deployment and market transformation activities encompass the laboratory's full range of technologies, which span the energy efficiency and renewable energy spectrum. NREL staff members educate partners on how they can advance sustainable energy applications and also provide clients with best practices for reducing barriers to innovation and market transformation.

NREL's mission is to be the leader in technology innovation and to advance renewable energy efforts around the world. Let NREL help propel your organization toward a more sustainable energy future.

For more information about NREL's deployment and market transformation activities, see our website at www.nrel.gov/tech_ deployment.

For more information about our project development and finance services, contact Michael Callahan at 303-275-4490 or michael.callahan@nrel.gov.

National Renewable Energy Laboratory 15013 Denver West Parkway

Golden, C0 80401

303-275-3000 • www.nrel.gov

NREL is a national laboratory of the U.S. Department of Energy, Office of Energy Efficiency and Renewable Energy, operated by the Alliance for Sustainable Energy, LLC.

NREL/FS-7A40-55107• January 2013

Front page photography (from the top): iStock 13737597; Dennis Schroeder, NREL 19893; iStock 12123595; Invenergy LLC, NREL 16040; from Ford Motor Company; Debra Lew, NREL 20528; Dennis Schroeder, NREL 19163

Printed with a renewable-source ink on paper containing at least $50 \%$ wastepaper, including $10 \%$ post consumer waste. 